\title{
GAGALNYA KOMUNIKASI POLITIK: STUDI SEMIOTIKA ROLAND BARTHES PADA IKLAN POLITIK ANDRE ROSIADE
}

\author{
Oleh:
}

\author{
SEPRI YUNARMAN \\ Dosen Universitas Dehasen Bengkulu
}

\begin{abstract}
This research aimed to describes the failure process of Andre Rosiade to be a Mayor candidate of Padang in 2013 from the perspective of political sociology, particularly political communication. This study found that Andre Rosiade started his socialization by using massive political advertising media. This effort was quite successful in raising the level of popularity and electability. However, in political communication only done (depending) with one political party, he failed. Roland Barthes called this phenomenon with the concept of the death of the author (The Death of the Author). This study was a qualitative research. Interviews, observation and literature study were data collection tools. The collected data were analyzed by the method negativa semiotics of Roland Barthes. The results showed that political communication built intensely by Andre through the media was not enough to convince the Party of Social Justice (PKS) to carry him become a Mayor. For Andre, political communication which he did deemed always to have denotative meaning, but it was considered to have connotative meanings for the political party.
\end{abstract}

Keywords: politics, political advertisement, Mayor, Indonesia

\section{PENDAHULUAN}

Sejak Indonesia memasuki era reformasi politik tahun 1998, penggunaan media iklan politik dalam melakukan komunikasi politik, menjadi kelaziman bagi partai politik ataupun kandidat, dalam rangka memaparkan visi misinya sehingga dapat membangun citra untuk mempertahankan kekuasaan, menghadapi kompetisi politik lokal, dan persaingan politik nasional. Setiap pihak, baik partai politik maupun peserta perorangan berusaha untuk meyakinkan para pemilih dengan menawarkan visi, misi, dan program partai dalam berbagai iklan politik.

Dalam Pemilu, partai politik biasanya berlomba-lomba memasang iklan di media massa untuk menarik simpati khalayak, dimana mereka mengharapkan iklan-iklan tersebut dapat meyakinkan masyarakat, untuk memilih partai politik yang memasang iklan. Asumsinya, semakin sebuah partai politik dikenal masyarakat lewat iklan-iklannya, maka semakin besar juga peluang keterpilihannya. Hal ini juga telah dijamin oleh UU Pemilu No.12 Tahun 2003 Pasal 73 telah mengatur bahwa media elektronik dan media cetak wajib memberikan kesempatan yang sama kepada peserta pemilu untuk memasang iklan politik dalam rangka kampanye.

Periklanan politik tabiatnya hampir sama dengan periklanan komersial. Sepak terjangnya merupakan bagian dari fenomena bisnis modern. Tidak ada perusahaan (baca: parpol) yang ingin maju dan memenangkan kompetisi bisnis (baca: Pemilu) tanpa mengandalkan iklan politik 
(Tinarbuko, 2009). Demikian pentingnya peran iklan politik dalam 'bisnis parpol"' sehingga salah satu para-meter kebonafitan parpol terletak pada seberapa banyak dana yang digelontorkan untuk iklan tersebut. Di samping itu, iklan politik merupakan jendela kamar dari sebuah parpol. Ia sanggup menghubungkan parpol dengan masyarakat, khususnya calon pemilih.

Selain itu, iklan politik merupakan salah satu sarana komunikasi politik yang berguna untuk menumbuhkan kesadaran khalayak akan citra baik seorang kandidat/partai politik, membangkitkan keinginan khalayak agar dapat menyukai program-program yang pemenangan yang dibuat oleh kandidat/partai politik, sehingga pada saat pemilu/pilkada diharapkan dapat memberikan pilihan politiknya kepada kandidat/partai politik tersebut.

Akan tetapi, komunikasi politik para kandidat/partai politik lewat iklan politik tidak selalu sesuai antara das sollen (harapan) dengan apa yang menjadi das sein (kenyatannya). Walaupun partai politik telah berusaha keras serta mengeluarkan biaya yang sangat besar untuk melakukan pemberitaan/iklan politik yang massif dalam berbagai media kampanye, tidak juga dapat menjamin bahwa masyarakat akan langsung memilih kandidat/partai politik tersebut dalam pilkada/pemilu. Asumsinya masyarakat pun sudah cerdas dalam menilai mana yang pencitraan saja dan mana yang benarbenar dapat dipercaya, ataupun karena memang mereka telah mempunyai pilihan tersendiri (ada hubungan persaudaraan ataupun memang termasuk tim sukses kandidat/partai politik tertentu).

Berbagai kajian mengenai pengaruh pemberitaan kampanye politik/iklan politik di Barat, khususnya di Amerika Serikat, mulai penelitian Paul Lazarsfeld dkk di Erie Country (Ohio, AS) tahun 1940, hingga penelitian di AS dan Inggris (Elihu Katz, 1989) menunjukkan bahwa pemberitaan kampanye politik tidak begitu berpengaruh untuk merubah perilaku pemilih, melainkan hanya akan memperteguh kecenderungan yang sudah ada. Karena memang iklan politik lebih banyak bersifat pasif yang mana komunikasi yang dibangun dominan bersifat satu arah, yakni hanya dari kandidat ataupun partai politik kepada khalayak. Sementara khalayak tidak mempunyai media untuk menyampaikan komunikasinya kepada kandidat/partai politik tersebut.

Selain itu, mengutip pendapat Stewart L.Tubb dan Sylvia Moss (dalam Susanto, 2012), bahwa "kampanye yang lebih banyak mendengar" serta tidak mengobral janji secara hiruk pikuk di media, dan lebih terfokus mendengarkan kehendak rakyat, dapat menjadikan kandidat atau partai politik dipilih oleh masyarakat. Sebagaimana apa yang dialami oleh Bill Clinton pada pemilihan Presiden Amerika Serikat, ia dapat melenggang ke Gedung Putih untuk pertama kalinya, karena lebih menyukai bertemu langsung dengan konstituen tanpa harus populer lewat iklan politik yang massif.

Kemudian, menurut Mulyana (2004), iklan politik tidak lebih efektif daripada komunikasi interpersonal, khususnya dalam keluarga, kelompok sebaya, klub, komunitas, agama, dan sebagainya. Ternyata komunikasi interpersonal lebih mempengaruhi khalayak daripada komunikasi massa dalam bentuk iklan politik diberbagai media dalam memilih kandidat atau partai politik. Karena iklan politik seringkali diposisikan hanya sebatas sebagai komunikasi penyampaian pesan yang bersifat linier, sehingga tidak menghiraukan umpan balik maupun dampaknya terhadap khalayak. Sementara komunikasi antarpersonal dalam komunitas-komunitas seperti yang dimaksud diatas, penyampaian pesan dapat terjadi secara aktif dan berantai, sehingga 
pada akhirnya menjadi sebuah komunikasi massa.

Jadi dalam komunitas tersebut, individu-individu yang ada didalamnya dapat berdiskusi dan saling bertukar informasi, sehingga pada akhirnya hasil diskusi ataupun pandangan yang dihasilkan, dapat mempengaruhi komunikasi massa yang dijadikan rujukan masing-masing individu. Sebagaimana yang dinyatakan oleh Joseph T. Klapper (Ibid_) bahwa kelompok-kelompok ini ditandai dengan pandangan-pandangan tertentu, dan sering menjadi sumber informasi serta dapat mengarahkan pandangan individu.

Fenomena iklan politik ini sangat penting untuk diteliti, karena memang fenomena ini cukup memberi dampak sosial yang serius dalam sebuah negara penganut demokrasi. Negara Indonesia yang notabenenya adalah negara penganut demokrasi --hal ini ditandai dengan banyaknya partai politik yang mengikuti pesta demokrasi- juga tengah mengalami degradasi keteladanan dalam berpolitik. Hampir setiap kandidat politik ataupun parpol politik saat ini sangat tertarik menggunakan media kampanye iklan politik, mulai dari spanduk, baliho, brosur, koran, radio maupun televisi. Iklan politik saat ini sudah menjadi sebuah kebutuhan dikalangan kandidat ataupun partai politik. Padahal biaya yang digunakan dalam penggunaan media iklan politik ini juga terbilang cukup besar. Sehingga, para kandidat atau pun partai politik diharuskan bekerja keras untuk mencari dan mengumpulkan dana kampanye, baik secara perorangan maupun secara lembaga. Maka tidak mengherankan banyak juga kita saksikan ada kandidat ataupun partai politik yang tersangkut masalah hukum akibat pengumpulan dana kampanye ini. Bahkan ada kasus yang cukup memperihatinkan, dimana seorang kepala daerah terpilih dalam proses pilkada yang telah diselenggarakan, dibatalkan oleh Mahkamah Konstitusi (MK) dan dilakukan pemilihan ulang, akibat ada indikasi penggunaan APBD dalam proses kampanye politiknya. Sebagaimana terjadi pada kasus calon Gubernur Alex Noerdin pada pilkada Sumatera Selatan.

Selain itu, dari beberapa penelitian akademis yang telah dikemukakan diatas, hasilnya membuktikan bahwa penggunaan media kampanye seperti iklan politik tidak terlalu efektif dan signifikan dalam pemenangan kandidat/partai politik. Bahkan sering kita temui dalam pilkada dibeberapa daerah, calon yang mempunyai modal finansial yang kuat disertai oleh dukungan jaringan parpol, serta menggunakan media iklan politik yang begitu massif, tetap saja mengalami kekalahan yang telak. Akan tetapi, tetap saja banyak calon/kandidat peserta pilkada diberbagai daerah di Indonesia yang semakin massif menggunakan metode kampanye lewat iklan politik.

Dalam proses pencalonan kandidat pada Pilkada Kota Padang tahun 2013, ada salah satu calon peserta Pilkada yang sangat antusias dalam melakukan komunikasi politik, baik melalui media iklan politik (baik di TV, radio, spanduk, baliho) serta juga komunikasi politik langsung (tatap muka) dengan tujuan untuk merebut sebanyak-banyaknya simpati dan dukungan masyarakat. Akan tetapi, komunikasi politik tersebut tidak terlalu berpengaruh terhadap pencalonannya sebagai peserta pilkada, bahkan ia gagal sebelum bertanding. Sehingga muncul asumsi dalam penelitian ini bahwa komunikasi politik yang ia lakukan gagal dalam mencapai tujuannya.

Beberapa penelitian terdahulu, yang berkaitan dengan komunikasi politik dalam iklan, diantaranya Suryatna yang melakukan penelitian tentang "Hubungan Karakteristik Pemilih Dan Terpaan Informasi Kampanye Politik Dengan Perilaku Memilih (Kasus Pemilihan Bupati dan Wakil Bupati Cianjur Tahun 2006)". Hasil penelitiannya menunjukkan bahwa perilaku pemilih dalam menerima dan 
mengolah pesan/informasi kampanye menunjukkan ketertarikan terhadap figur dan dalam menyeleksi pesan kampanye sebagian besar tidak berperilaku selektif, bersikap terbuka, menilai dan membandingkan pesan semua pasangan calon. Selain itu, perilaku pemilih dalam menentukan pilihan politiknya sebagian besar dilakukan setelah memiliki informasi dari semua pasangan calon dan alasan yang mendasari putusannya adalah figur pasangan calon daripada faktor visi dan misi pasangan calon atau partai politik pengusungnya. Kemudian, hubungan antara karakteristik pemilih dan terpaan informasi kampanye dengan perilaku memilih menunjukkan hubungan nyata baik secara parsial maupun serentak.

$$
\text { Selanjutnya Rozak (2009) }
$$

melakukan penelitian tentang "Iklan

Politik Caleg Dalam Persepsi Pemilih Pemula" yang dilakukan di kota Surakarta provinsi Jawa Tengah. Tujuan dari penelitian ini untuk mengetahui bagaimana persepsi pemilih pemula terhadap iklan politik caleg di media luar ruang. Secara umum data hasil penelitian menunjukkan bahwa pemilih pemula di SMA Negeri III Surakarta menilai hampir semua bentuk media maupun pesan kampanye dalam iklan politik caleg DPRD II Surakarta memiliki kesamaan satu sama lainnya sehingga dinilai tidak kreatif. Selain itu, pemilih pemula juga menilai bahwa penggunaan pesan-pesan kampanye dalam iklan politik oleh para caleg merupakan bentuk pengenalan dan pencitraan diri saja.

Selain itu, Baiquni (2009) juga melakukan penelitian "Pengaruh Tingkat Pengetahuan Tentang Iklan Politik Televisi Terhadap Sikap Politik Pemilih Pemula Di Kecamatan Klojen Kota Malang. ”Tujuan penelitian ini adalah untuk mengetahui tingkat pengetahuan iklan politik televisi pemilih pemula, sikap politik pemilih pemula dan pengaruh tingkat pengetahuan iklan politik televisi terhadap sikap politik pemilih pemula kota Malang. Hasil penelitian menunjukkan bahwa tingkat pengetahuan iklan politik pemilih pemula kota Malang mempunyai pengaruh terhadap sikap politiknya dalam pemilihan Presiden dan Wakil Presiden tahun 2009. Mayoritas pemilih pemula menilai bahwa pasangan kandidat SBY-Boediono yang paling banyak diketahui dan dipahami iklan politik televisinya. Sehingga hal itu berpengaruh dan cukup efektif dalam menggerakkan dan mempengaruhi sikap politik pemilih pemula untuk dapat memilih pasangan SBY-Boediono dalam Pilpres 8 Juli 2009.

Sementara itu, Marissa melakukan penelitian tentang "Pengaruh Iklan Politik Dalam Pemilukada Minahasa Terhadap Partisipasi Pemilih Pemula di Desa Tounelet Kecamatan Kakas." Hasil penelitian ini memperoleh kesimpulan bahwa Iklan Politik dalam Pemilukada mempunyai pengaruh yang cukup kuat terhadap partisipasi pemilih pemula atau sekitar $17,30 \%$ sedangkan sisanya ditentukan oleh variabel lainnya, seperti faktor lingkungan, keluarga, dan nilai-nilai sosial yang dianutnya.

Sebenarnya, masih cukup banyak penelitian yang membahas tentang komunikasi lewat iklan politik. Akan tetapi, penulis hanya mengemukakan beberapa penelitian saja, yang dinilai paling berkaitan dengan penelitian ini. Dari beberapa penelitian yang dikemukakan diatas, dapat kita tangkap ada dua pandangan yang cukup berbeda dalam menganalisis pengaruh iklan politik terhadap perilaku pemilih. Pandangan pertama, menyatakan bahwa iklan politik memiliki pengaruh terhadap perilaku pemilih, semakin banyak informasi yang didapat oleh pemilih tentang diri kandidat lewat iklan politiknya, maka hal tersebut dapat membuat pemilih memberikan pilihan politiknya terhadap kandidat tersebut. Sedangkan pandangan lainnya menyatakan bahwa iklan politik tidak dapat membentuk/mempengaruhi perilaku pemilih. Maka penelitian yang akan dilakukan disini akan mengikuti 
argumentasi pandangan yang kedua, yakni memandang bahwa iklan politik tidak mempunyai pengaruh terhadap perilaku pemilih. Dalam artian komunikasi politik berbentuk iklan politik seringkali gagal dalam mencapai tujuannya. Tujuan dari penelitian ini adalah untuk menjelaskan tentang proses kegagalan Andre Rosiade untuk menjadi calon Walikota Padang periode 2014-2019 yang dilihat dari aspek komunikasi politik yang ia lakukan.

\section{METODE PENELITIAN}

\section{Penelitian ini menggunakan} pendekatan kualitatif dengan tipe deskriptif, dimana selama proses pengumpulan data di lapangan, penulis mengumpulkan data serta informasi dalam bentuk kata-kata lisan maupun tulisan, juga data dan informasi dalam bentuk perbuatan-perbuatan yang dilakukan oleh informan, untuk kemudian dianalisis. Pengumpulan data dilakukan dengan beberapa metode yang sesuai dengan kebutuhan penelitian, yaitu wawancara mendalam, observasi, dan dokumentasi.

Teknik triangulasi penulis gunakan untuk mengklarifikasi data yang telah didapat dengan mempertanyakan pernyataan yang dibuat oleh informan. Adapun pihak subyek triangulasi diantaranya, bakal calon itu sendiri (Andre), pimpinan lembaga konsultan politik Andre (Incost), beberapa seorang kader PKS yang tidak penulis sebutkan identitasnya

Analisis data dilakukan dalam beberapa tahap. Pada tahap awal, analisis data dimulai dengan melakukan proses pengumpulan data dengan menggunakan studi literatur atau studi dokumentasi. Dilanjutkan dengan melakukan wawancara mendalam terhadap informan, dimana data yang didapat ditulis dalam catatan lapangan. Setelah melakukan pengumpulan data, penulis tahap selanjutnya adalah reduksi data dengan mengorganisasi data dan informasi dari hasil wawancara dan studi dokumentasi. Lalu data ditafsirkan dan diseleksi sehingga relevan dengan fokus masalah yang diteliti. Setelah reduksi data selesai, penulis melakukan penyajian data berupa teks naratif dengan menyederhanakan informasi yang kompleks ke dalam kesatuan bentuk yang lebih mudah dipahami untuk ditarik kesimpulannya.

Adapun model analisis yang akan peneliti gunakan dalam penelitian ini adalah model analisis semiotika Roland Barthes yang memiliki dua variabel konsep, yakni signifier dan signified. Adapun hubungan signifier dan signified ini menurut Barthes, dapat secara langsung dan jelas (iconic), namun dapat pula serampangan (arbitrates). Sementara itu, tanda (sign) merupakan komunikasi yang memiliki makna laten dan manifest. Pada awalnya mempunyai makna laten kemudian menjadi manifest dapat menggambarkan aspek nilai-nilai moral, hasrat-hasrat atapun perilaku dari seorang viewer.

\section{HASIL DAN PEMBAHASAN}

\section{Sekilas tentang Profil Andre Rosiade}

Andre dilahirkan di Kota Padang, Sumatera Barat, pada tanggal 7 November 1978 (umur 35 tahun) dari pasangan Yanziwar Ade dan Rosita Yurnetty. Andre melalui masa kecil dan pendidikan dasar sampai menengah di Padang. Ia lalu melanjutkan pendidikan tingginya di Universitas Trisakti, Jakarta. Semasa kuliah ia ia pernah menjadi Presiden Mahasiswa periode 2000-2001.

Saat ini Andre dikenal sebagai pengusaha muda sukses yang memulai usahanya dari bawah. Disamping kesibukannya sebagai pengusaha, Andre juga aktif di berbagai organisasi, diantaranya sebagai Pengurus HIPMI Sumbar sejak 2011 dan Ketua Gerakan “Ayo Jadi Pengusaha” Wil. Sumbar BPD HIPMI Sumbar.

\section{Sumber Daya Andre Rosiade}

Beberapa sumber daya (capital)

yang dimiliki Andre Rosiade dalam 
berkompetisi di dunia politik adalah: (1) sumber daya politik. Adapun yang dimaksud dengan sumber daya politik diantaranya adalah sumber daya informasi, sumber daya finansial, sumber daya jaringan (Partai Politik maupun organisasi massa) dan sumber daya teknologi informasi. (2) Sumber Daya Finansial. (3) sumber daya jaringan, yaitu lingkungan pengusaha, teman-teman aktivis selama kuliah, dan teman-teman dan komunitas di organisasi Dewan Tani Indonesia. (4) sumber daya informasi (konsultan politik), yaitu lembaga Incost, (5) Sumber Daya Teknologi Informasi (media arus utama, Blog, Website, Media Sosial), dan (6) Sumber Daya Manusia (Tim Sukses).

\section{Strategi Komunikasi Politik Andre Rosiade}

Salah satu strategi dalam politik adalah strategi pencitraan. Politik pencitraan di alam demokrasi Indonesia saat ini merupakan suatu keniscayaan. Banyak faktor yang menyebabkan hal ini terjadi. Salah satunya karena UndangUndang memang telah mengamanahkan pemilihan langsung oleh rakyat. Sebagai dampaknya setiap calon peserta pemilu/pilkada harus massif memperkenalkan diri kepada masyarakat.

Kaitannya dengan Andre, ia telah merancang beberapa program politik pencitraan. Ia menyentuh benak publik dengan membawa berbagai program issu politik, melakukan pendekatan ke ragam kelompok usia, serta menggunakan berbagai media komunikasi politik. Mulai dari menebar pesona gambar dalam iklan politik, sampai blusukan ke tengah-tengah masyarakat. Hal ini dilakukan tidak lain, karena Andre sangat meyadari bahwa dirinya bukanlah siapa-siapa dalam kancah politik di Kota Padang, dan banyak masyarakat yang belum mengenal dirinya baik secara watak personalnya maupun pemikirannya.

\section{Fenomena Iklan Politik di Indonesia}

Babak baru kehidupan berpolitik di Indonesia yang ditandai dengan penerapan sistem multipartai telah melahirkan pula berbagai fenomena baru yang dilakukan oleh partai politik dalam upayanya meraih simpati dan suara rakyat. Sebagian kalangan menilai fenomena ini sebagai politik tak berjiwa yang telah menggeser peran dan fungsi partai politik yang saat ini lebih berorientasi kepada upaya meraih dukungan sebanyak-banyaknya tanpa memperdulikan program, visi dan misi yang seharusnya ditawarkan kepada rakyat Indonesia sebagai solusi permasalahan negara ini.

Iklan politik yang merupakan suatu bentuk pemasaran politik, yang biasanya disajikan secara berulang-ulang, akan dapat menarik perhatian orang. Menurut Jalaludin Rakmat, apabila suatu hal disajikan secara berulang-ulang akan dapat menarik perhatian dan akhirnya mempengaruhi bawah sadar seseorang. Selain itu, Wells, Burnett \& Moriarty (2011) menyatakan bahwa seseorang butuh untuk mendengar atau melihat sesuatu minimal tiga kali sebelum hal yang didengar atau dilihat menempel dalam memori seseorang.

Informasi yang berasal dari terpaan iklan dan kesan yang terbentuk dari iklan dapat mempengaruhi sikap terhadap obyek iklan dan akhirnya dapat mempengaruhi tindakan khalayak. Fenomena-fenomena tersebut menurut Eep Saefulloh Fatah dinamakan dengan "demokrasi electoral" (electoral democracy) yaitu suatu kondisi iklim demokrasi yang memfasilitasi terbangunnya pemilih (electorate) sebagai penentu.

Selain itu terdapat perubahan langgam hubungan di antara partai politik dengan pemilihnya yang kemudian membentuk pasar politik (political market) dengan aktivitas utama dari pasar politik tersebut yaitu pertukaran (exchange) antara partai politik dengan pemilihnya. Menurut Adnan Nursa, terdapat 5 (lima) faktor yang 
membuat pemasaran politik berkembang di Indonesia :

1. Sistem multipartai yang memungkinkan siapa saja boleh mendirikan partai politik dan memiliki konsekuensi akan timbulnya persaingan tajam antar partai politik.

2. Pemilih telah lebih bebas menentukan pilihannya dibandingkan Pemilu sebelumnya, sehingga syarat bagi penerapan political marketing terpenuhi.

3. Partai-partai lebih bebas menentukan platform dan identitas organisasinya.

4. Pemilu merupakan momentum sejarah yg penting dalam perjalanan bangsa sehingga pihak-pihak berkepentingan, terutama elit politik akan berusaha keras untuk ambil bagian.

5. Sistem pemilihan anggota parlemen, Dewan Perwakilan Daerah, dan Presiden secara langsung, yang kelak akan diikuti oleh pemilihan Gubernur, Bupati dan Walikota.

Kelima faktor ini merupakan alasan utama yang menjadi pemikiran pelaku politik, dalam hal ini partai politik agar aktivitas politik mereka dapat diterima oleh masyarakat. Selain itu juga sebagai wahana pembuktikan eksistensi mereka dalam dunia perpolitikan.

Jadi ujung dari pemasaran politik tersebut adalah iklan politik. Semakin gencar sebuah partai untuk menyampaikan ide-ide politiknya, maka semakin gencar pula penggunaan media kampanye iklan politik. Apalagi dengan jumlah partai yang cukup banyak, serta setiap kandidat diberi ruang pula untuk memenangkan pertarungan itu secara bebas, maka tentu iklan politik menjadi sebuah pilihan utama yang mewarnai proses pemilu maupun pemilukada yang ada di Indonesia.
Terkait penggunaaan iklan politik di Indonesia, data AC Nielsen menunjukkan bahwa belanja iklan 41 partai politik pada Pemilu tahun 1999 mencapai Rp. 35,6 milyar dengan total dana kampanye partai politik dalam Pemilu tahun 1999 berdasarkan iklan yang ditayangkan dari 10 partai politik yang paling besar mengalokasikan dana adalah Rp. 34 milyar.

Sedangkan pada Pemilu 2004, penggunaan strategi periklanan dalam kampanye politik semakin semarak. Belanja iklan nasional partai politik mengalami peningkatan yang signifikan. Hasil riset Nielsen Media Research (NMR) periode Maret 2004 menunjukkan bahwa total belanja iklan partai politik mencapai Rp. 112,2 milyar. Untuk Pemilu tahun 2009, total belanja iklan partai politik peserta Pemilu diperkirakan naik menjadi sekitar Rp 2 triliun. Semakin ketatnya aturan bagi partai politik yaitu dengan adanya aturan parliamentary threshold dan electoralthreshold berdasarkan UU No.10 tahun 2008 tentang Pemilihan Umum Pasal 202 ayat 1 , diyakini semakin membuat belanja iklan partai politik melonjak tajam. Untuk lebih jelasnya dapat dilihat pada tabel berikut ini.

\section{Tabel Biaya Iklan Partai Politik dalam} Pemilu di Indonesia

\begin{tabular}{|l|c|c|c|}
\hline No & $\begin{array}{c}\text { Tahun } \\
\text { Pemilu }\end{array}$ & $\begin{array}{c}\text { Jumlah Peserta } \\
\text { Pemilu }\end{array}$ & $\begin{array}{l}\text { Total Biaya } \\
\text { Iklan Politik }\end{array}$ \\
\hline 1 & 1999 & 48 Partai Politik & Rp. 35,6 milyar \\
\hline 2 & 2004 & 24 Partai Politik & Rp. 112,2 milyar \\
\hline 3 & 2009 & 34 Partai Politik & Rp 2 triliun. \\
\hline
\end{tabular}

Sumber : Hasil riset Nielsen Media Research (NMR)

Dengan iklan mereka tak hanya dapat melakukan perjumpaan dengan rakyat Indonesia yang terlampau banyak itu, namun dengan iklan mereka mampu memanipulasi diri agar tampak baik dan mengagumkan. Agaknya sebab itu pula, dalam penampilan mereka di iklan-iklan, para politisi itu tak menjual programnya, tapi bagaimana menampilkan citra yang baik, dalam durasi beberapa menit. Pesanpesan politiknya dibuat sesingkat mungkin, 
supaya dapat mempengaruhi kesadaran para pemilih yang mengambil kesimpulan berdasar low information rationality.

\section{Narsisme Iklan politik Andre (Off Air dan On Air)}

Cikal bakal iklan politik Andre dimulai sejak tahun 2012 dengan tersebarnya baliho berisi tagline "Ayo Jadi Pengusaha" di kota Padang. Dikatakan Andre, tagline tersebut memang ia gunakan untuk mensosialisasikan dirinya sebagai pengusaha muda yang sukses. Tagline "Ayo Jadi Pengusaha" bukanlah ajakan bermakna sebenarnya. Namun ajakan tersebut juga berarti sebuah perkenalan Andre kepada masyarakat bahwa Andre akan maju ke pentas Politik Kota Padang tahun 2013.

Ternyata baliho yang berisi ajakan "Ayo Jadi Pengusaha" tidak efektif untuk menaikkan elektabilitas Andre Rosiade dimata publik. Beberapa bulan sejak sosialisasi awal ini, Andre dan timnya melakukan survey. Hasil survey hanya menunjukkan angka dibawah 2 persen. Hal ini membuat Andre dan timnya berpikir keras untuk mencari formulasi baru dalam menaikkan tingkat popularitas dan elektabilitasnya. Salah satu pokok pikiran yang dihasilkan adalah Andre harus berterus terang kepada publik, ia bersilaturahmi ke berbagai media massa untuk memberitahukan bahwa ia memang berniat untuk maju sebagai calon pemimpin Kota Padang. Hal inilah yang mendasarinya untuk merubah konten tagline-nya dari "Ayo Jadi pengusaha" menjadi "Untuk Kota Padang yang Lebih Baik." Karena memang menurut Andre, Kota Padang butuh perubahan ke arah yang lebih baik. Dalam penilaiannya, Kota Padang dalam kepemimpinan Fauzi Bahar sudah sangat tertinggal, terutama generasi mudanya. Sedangkan program-program yang dicanangkan pemerintah banyak yang hanya pencitraan Semata. Maka semenjak itulah, semakin bermunculan baliho Andre dengan tagline baru.

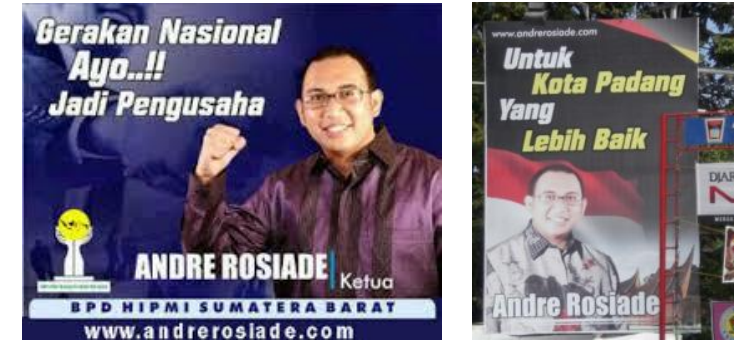

Gambar 1: Baliho sebelum dan sesudah Andre menyatakan akan maju ke pentas Pilkada

Selain memasang iklan luar ruang seperti baliho dan spanduk, Andre secara masif juga menerbitkan iklan-iklan politik di media elektronik seperti Radio Arbes FM dan muncul dalam acara talkshow di tv lokal.

\section{Analisis Tanda dan Makna Semiotis Komunikasi Politik Andre dalam Bentuk Media Iklan \\ Sebagaimana \\ yang telah} dikemukakan di depan, bahwa iklan politik merupakan salah satu bentuk komunikasi politik yang bertujuan untuk menyampaikan informasi yang baik seputar tentang si-pengiklan kepada publik, kemudian berharap pihak yang dituju dapat mendukung bahkan mengikuti maksud yang dikehendaki oleh si pengiklan tersebut. Jika memang terjadi demikian, maka iklan politik tersebut dapat dikatakan berhasil tujuannya. Akan tetapi, jika yang terjadi sebaliknya, maka iklan politik tersebut dapat dikatakan gagal mencapai tujuannya.

Hal ini dialami oleh Andre Rosiade. Dimana iklan politik yang dilakukannya secara dini dan massif tersebut mengalami kegagalan dalam mencapai tujuannya. Tujuannya tidak lain, bahwa dengan melakukan iklan politik dengan gencar, maka Andre akan semakin dikenal publik di Kota Padang, selanjutnya partai politik akan tertarik untuk mengusungnya menjadi salah seorang peserta dalam pemilihan Walikota Padang tahun 2013 yang lalu. 


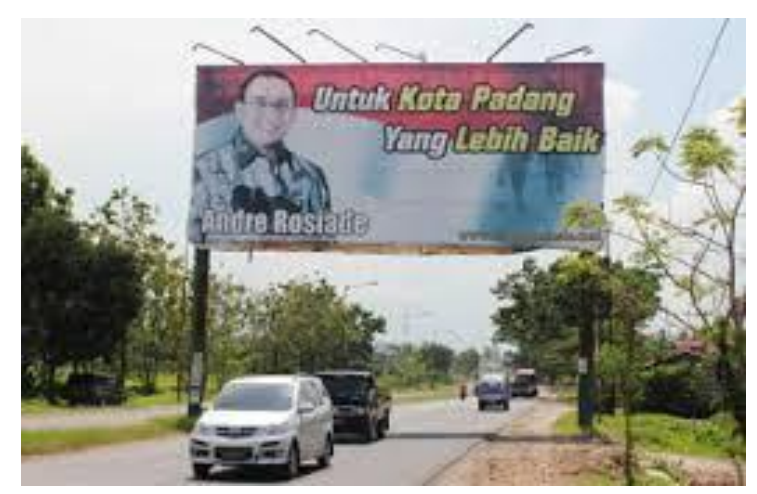

Gambar 2: Baliho Andre di salah satu jalan тепији BIM

Jika mengkaji tentang strategi komunikasi Politik Andre lewat iklan dengan semiotika, maka ada dua aspek tanda yang dapat dilihat yakni gambar (foto) Andre itu sendiri, kemudian juga kalimat-kalimat yang ada didalamnya. Hal ini sesuai dengan pendapat Sobur bahwa tanda dalam iklan terdiri dari tanda-tanda verbal dan tanda nonverbal. Tanda verbal mencakup bahasa yang kita kenal, sedangkan tanda nonverbal bisa berupa gambar ataupun bentuk iklan tersebut. Sementara itu, Charles Sander Pierce juga membuat klasifikasi tentang tanda, yakni ada ikon (foto, gambar atau lukisan), Indeks (penunjuk jalan) dan Simbol (bahasa).

Adapun beberapa aspek sign (tanda) yang melekat pada iklan politik Andre diantaranya adalah 'simbol.' Dimana aspek signifiernya (penanda) dapat dilihat dari tagline iklan politik Andre ketika baru sosialisasi dengan menggunakan kalimat "Ayo..!! Jadi Pengusaha". Bagi Andre tagline ini tentu mempunyai makna yang menyatakan bahwa ia ingin benar-benar berbuat untuk daerah dengan mengajak para pemuda untuk jadi pengusaha yang sukses.

Signifier (penanda) berupa simbol tagline "Ayo..!! Jadi Pengusaha" ini menimbulkan aspek signified tersendiri bagi PKS, partai politik yang diingini Andre untuk mengusung dirinya. Pada tahap pertama (denotatif) tanda tersebut tentu dianggap PKS bermakna sebagai sebuah ajakan yang sangat mulia kepada para generasi muda, khususnya di Kota Padang. Kenyataannya selama ini memang Andre telah berkecimpung di dunia wirausaha, bahkan termasuk salah satu pengusaha asal Kota Padang yang terbilang sukses dalam menekuni usaha bisnisnya. Jadi, ajakannya merupakan sesuatu yang wajar dilakukan dalam rangka berbuat untuk daerah.

Namun, pada tingkat kedua (connotatif signified) PKS memaknai bahwa iklan di baliho Andre yang bertagline "Ayo..!! Jadi Pengusaha" ini merupakan cara atapun bentuk perkenalan awal Andre kepada masyarakat yang menyatakan bahwa ia ingin menjadi pemimpin di Kota Padang. Mengapa demikian? Pandangan PKS ini didasarkan bahwa tindakan Andre yang muncul ke publik lewat baliho-balihonya yang bertagline "Ayo..!! Jadi Pengusaha" ini ia lakukan ketika sudah mendekati momen Pilkada Kota Padang. Tentu tindakan Andre ini akan memunculkan pertanyaan yang beragam di benak publik. Semisal, kenapa ia melakukan itu tidak sejak dulu jauh sebelum isu Pilkada berhembus di publik. Jadi, pandangan PKS yang menyatakan bahwa Andre memperkenalkan bahwa dirinya ingin maju dalam pentas Pilkada lewat baliho-baliho tersebut cukup mempunyai bukti yang kuat.

Selain itu, dengan tersebarnya baliho Andre di setiap sudut Kota Padang dalam waktu yang cukup lama, dianggap merupakan suatu bentuk tindakan yang mencuri start kampanye Pilkada. Hal ini dikarenakan bahwa, jika Andre membuat baliho dengan tagline "Calon Walikota Padang" tentu akan mendapat teguran dari berbagai pihak, termasuk penyelenggara Pilkada. Namun, dengan membuat baliho ber-tagline "Ayo..!! Jadi Pengusaha" ini tentu akan menguntungkan posisi Andre, dimana pihak lain tidak dapat mempermasalahkannya secara aturan Pilkada, sementara dengan baliho tersebut 
dirinya telah berkampanye jauh-jauh hari sebelum jadwal resminya.

Selain itu, aspek tanda (sign) berikutnya pada iklan politik Andre yang lain yaitu simbol berupa kalimat "Untuk Kota Padang yang Lebih Baik". Tanda ini bagi Andre mempunyai makna bahwa ia merasa dapat menjadi sosok 'pahlawan' dalam menyelesaikan masalah dalam kehidupan masyarakat Kota Padang. Ia menganggap bahwa dirinya adalah orang yang berpengalaman, mengetahui masalah daerah dan juga solusi untuk mengatasinya. Oleh karena itu, ia menawarkan sebuah perubahan kepada masyarakat Kota Padang dengan tagline "Untuk Kota Padang Lebih Baik" dalam setiap media sosialisasinya. Kemanapun pergi, Andre selalu menawarkan programprogram yang bersifat problem solving kepada masyarakat.

"Jadi niat untuk menjadi Walikota Padang ini karena kegelisahan, melihat terus terang kota padang dibawah kepemimpinan Fauzi Bahar jauh merosot dan tertinggal dibanding ibukota lain di Sumatra. Bahkan dikota-kota lain di Sumatra Barat aja sudah mulai tertinggal. Satu contoh disektor pendidikan, jauh tertinggal dari Kota Bukittinggi. Itulah yang memicu dan memacu keinginan kami generasi muda untuk maju pada pilkada Kota Padang. Nah, tentu setelah keinginan itu muncul, kami diskusikan dengan teman-teman, akhirnya pada Januari 2012 mulailah kami melakukan sosialisasi. Karena kalau kita kalau bukan kita siapa lagi melakukan perubahan, ya uda, kami memutuskan mencoba memberanikan diri untuk mencoba membangun mimpimimpi besar untuk melakukan perubahan di Kota Padang. Jadi program kami tidak banyak, tapi program-program dasar yang kita rasakan memang inilah kebutuhan awal, langkah awal untuk melakukan perubahan di Kota Padang. Kontennya itu Andre Rosiade untuk Kota Padang yang lebih baik, itu taglinenya ya. Lalu yang kita tawarkan itu sebenarnya itu perubahanperubahan. Bahwa Andre Rosiade sebagai calon pemimpin bisa membawa perubahan-perubahan untuk Kota Padang," lanjut Andre.

Aspek signifier (penanda) yang ada pada iklan Andre ini juga memunculkan Aspek signified bagi PKS. Aspek signified ini juga terbagi menjadi dua, yakni denotatif signified (petanda denotatif) dan connotatif signified (petanda konotatif). Menurut PKS, aspek denotatif signified (petanda denotatif) adalah tagline "Untuk Kota Padang yang Lebih Baik" digunakan Andre itu dengan tujuan untuk merebut simpati publik. Jadi dengan membuat tagline 'Untuk Kota Padang yang Lebih Baik' maka orang akan menilai sosok Andre merupakan seorang pahlawan yang akan merubah nasib masyarakat Kota Padang kedepannya.

Akan tetapi, simbol yang berupa tagline 'Untuk Kota Padang yang Lebih Baik' ini juga mempunyai aspek connotatif signified bagi PKS. Dimana PKS menilai tagline itu hanya 'citra' semata. Karena menurut mereka Andre dianggap memang belum mempunyai pengalaman dalam mengurus pemerintahan jika dibandingkan dengan pak Emzalmi. Dari riwayat hidupnya, Andre bukanlah seorang abdi Negara (PNS) yang terlibat dalam urusan birokrasi, namun ia merupakan seorang pengusaha yang menekuni multibisnis. Hal ini juga yang mendasari PKS untuk lebih memutuskan berkoalisi dengan Emzalmi daripada Andre, sekalipun secara survey, popularitas dan elektabilitas Andre jauh lebih tinggi dari Emzalmi. Selain itu, PKS juga menilai Emzalmi telah mempunyai 
track record yang baik serta memang mempunyai aura kecocokan tersendiri dengan pak Mahyeldi, sebagai calon Walikota dari PKS. Sebagaimana yang diungkapkan oleh Muhidi ketika peneliti menanyakan mengapa lebih memilih Emzalmi daripada Andre untuk dipasangkan dengan pak Mahyeldi.

"Kita kan punya analisis terkait dengan pak Emzalmi, dia putra asli daerah, berpengalaman, track recordnya sudah terbukti, chemestrynya sudah teruji juga dengan pak Mahyeldi. Sebenarnya semuanya sudah dibuat analisis di DPP. Dengan Andre bagaimana pula analisisnya, begitu juga yang lain. Sudah itu kita nunggu aja lagi. Sementara terkait hasil survey Andre lebih tinggi dari Emzalmi, kan itu bukanlah satu-satunya pertimbangan. Coba siapa yang menyangka pasangan De-Je ini masuk dua besar, kan gak ada. Jadi survey salah satu indikatorsaja, apalagi kalau surveynya kita lihat lagi dua hal pertama independensinya, teknologinya, orang membawa quisioner itukan perlu kita pertanyakan juga. Tapi yang perlu kita tegaskan bahwa survey itu salah satu bagian bukan satu-satunya," ujarnya

Selanjutnya, aspek sign (tanda) dalam bentuk simbol 'Untuk Kota Padang yang Lebih Baik' dalam iklan politik Andre juga mempunyai petanda (signified) lain bagi Andre yaitu mencitrakan dirinya seorang 'sang pembaharu'. Pada tingkatan makna pertama (petanda denotatif), Andre dinilai bahwa ia ingin menunjukkan bahwa ia memang membawa sesuatu yang 'baru' bagi masyarakat Kota Padang. Kota Padang yang dilihatnya kian terpuruk, maka dengan demikian ia membawa program-program perubahan untuk Kota Padang yang lebih baik kedepannya.

"Pertama muncul sendiri, karena kegelisahan melihat Kota Padang yang terpuruk ditambah dorongan teman-teman. Karena kalau bukan kita siapa lagi melakukan perubahan.Ya uda, kami memutuskan mencoba memberanikan diri untuk mencoba membangun mimpi-mimpi besar untuk melakukan perubahan di Kota Padang. Alhamdulillah program-program yang kami tawarkan pun sangat dterima oleh masyarakat. Jadi program kami dak banyak, itu program-program dasar yang kita rasakan memang inilah kebutuhan awal, langkah awal untuk melakukan perubahan di Kota Padang," jelas Andre.

Akan tetapi pada tingkatan makna kedua (connotatif signified), PKS menilai, baik tagline ataupun program yang Andre munculkan tersebut merupakan sebuah 'topeng politik' saja untuk mengecoh pikiran publik. Hal ini dikarenakan program yang ia bawa ke publikbukanlah sesuatu yang istimewa untuk Kota Padang. Bahkan hal tersebut terkesan biasa saja jika dibandingkan dengan program dari bakal calon lainnya. Misalnya, Program Drs. Ibrahim, MM ataupun Program unggulan Mahyeldi Anshyarullah, S.P, yang mana secara garis besar program yang mereka buat lebih pada penataan tata kota, pendidikan dan kesehatan gratis, pembukaan lapangan pekerjaan. Bahkan menurut PKS, pada akhirnya tidak ada partai yang memang mempunyai keinginan yang kuat untuk mengusung Andre.

"Biasa aja, kan semua orang bisa mengatakan itu. Akan tetapi karena dia sudah duluan memakai tagline itu, jadi gak mungkin yang lain menggunakannya lagi. Kan wajar juga itukan pilihan. Tapi kita lihat realitanya ternyata partai lain gak ada juga yang ngotot-ngotot juga untuk meminangnya. Kalau dibilang dia dilarang siapa juga siapa yg melarang? Terkait yang tadi ada pernyataan ada beberapa 
elit PKS yang melarang saya tidak tau juga siapa itu. Inikan salah. Jadi dalam organisasi jelas salah saya sudah memberitahukan bahwa tidak ada kata putus kepada calon. Kata putus itu ada di DPP. Kita boleh punya keinginan tapi keinginan kita itu harus memyesuaikan dengan mekanisme DPP. Itu yang saya lakukan," jelas Muhidi.

Aspek sign (tanda) berikutnya yang ada didalam iklan poitik Andre adalah 'ikon.' Adapun aspek signifiernya dapat dilihat dari gambar atau foto Andre dalam berbagai iklan politiknya, terutama gambar didalam baliho yang menampakkan wajah tampandengan mimik wajah tersenyum serta body language (bahasa tubuh) Andre yang menampakkan fostur yang gagah. Dengan gambar ini Andre ingin mencitrakan dirinya sebagai calon pemipin dari kalangan 'tokoh muda.' Menurutnya, sosok 'tokoh muda' ini dianggap sebagai suatu 'nilai tambah' untuk ditonjolkan ke publik. Hal ini, dikarenakan banyak tokohtokoh atau bakal calon yang akan maju menjadi pemimpin Kota Padang saat itu berasal dari 'kaum tua.' Bahkan Andre mengaku bahwa banyak elit politik maupun pimpinan parpol yang menganggap mereka belum pantas untuk menjadi pemimpin Kota Padang.

"Jadi niat untuk menjadi Walikota Padang ini muncul karena kegelisahan terus terang melihat Kota Padang dibawah kepemimpinan Fauzi Bahar jauh merosot dan tertinggal dibanding ibukota Provinsi lain di Sumatra. Bahkan dikota-kota lain di Sumatra Barat aja sudah mulai tertinggal. Satu contoh disektor pendidikan, jauh tertinggal dari Bukittinggi. Itulah yang memicu dan memacu keinginan kami generasi muda untuk maju pada Pilkada Kota Padang. Nah, tentu setelah keinginan itu muncul, kami diskusikan dengan teman-teman, akhirnya akhir Januari 2012 mulailah kami melakukan sosialisasi," ungkap Andre.

“ Kami

mulai

mensosialisasikan diri dan program bahwa kami generasi muda ingin maju di Pilkada Kota Padang. Majunya kami itu awalnya kan menjadi cemoohan khususnya elit-elit politik dan pimpinan partai politik. Elit-elit yang sudah establish ditambah pmpinan parpol yang memandang sinis kami, bahkan mengatakan'anak ketek kegadang-gadangan.' tapi Alhamdulillah karena kerja keras, karena masyarakat Kota Padang memang merindukan perubahan. Mereka membutuhkan pemimpin yang bisa mewujudkan mimpimimpi mereka," lanjut Andre.

Ikon dengan gambar sosok 'Andre Muda' yang tercermin dalam iklan politik Andre Rosiade memiliki signified (petanda) tesendiri bagi PKS. Pada tingkatan makna pertama (petanda denotatif) PKS menilainya bahwa Andre seorang tokoh muda yang mempunyai sikap pemberani dengan mengiklankan dirinya sebagai calon pemimpin muda untuk Kota Padang. Namunpada tingkatan makna kedua (petanda konotatif), ikon 'tokoh muda' ini bagi PKS merupakan sebuah tantangan yang serius dalam perebutan kekuasaan. Hal ini dikarenakan, kedepan 'Andre muda' bisa menjadi rival yang tangguh dikemudian hari nanti. Oleh karena itu, sosok Andre yang disebut sebagai 'tokoh muda' menjadi perhitungan politik tersendiri bagi PKS dimasa yang akan datang. Sebagaimana disampaikan oleh Andre dalam pernyataannya.

"Inilah yang saya tangkap ya, mereka tidak ingin ada dua matahari. Andre initidak ada apaapanya dan media darling kan, tapi bisa-bisanya jadi wakil pak 
Mahyeldi, jadi takut nanti pak Mahyeldi hilang diperedaran. Jadi itu yang saya tangkap dari psikologis mereka," ungkap Andre.

Selain itu, informasi lainnya juga peneliti dapatkan dari seorang 'kader' PKS. Sebagai kader yang banyak berinteraksi dengan struktur DPD PKS Kota Padang, ia cukup mengetahui tentang proses komunikasi politik Andre dan DPD PKS. Dimana ia sedikit memberikan bocoran tentang pandangan beberapa elit struktur DPD PKS Kota Padang terhadap Andre. Menurutnya, memang ada sedikit kekhawatiran dari pihak DPD yang melihat semangat Andre yang menggebu-gebu tersebut. Ditambah pula sosoknya yang masih muda dan enerjik sehingga ditakutkan akan menjadi rival yang tangguh dimasa yang akan datang.
"Saya
lihat
salah
satu
kekhawatiran PKS adalah karena

Andre masih muda. Orangnya enerjik, bahkan kalo berpasangan dengan pak Mahyeldi, secara tampilan dapat mengalahkan pak Mahyeldi. Jaringannya kuat, itu yg membuat PKS tidak "respect" dengan dia. Karena, kedepan bisa diprediksi Andre akan menjadi pesaing yang tangguh bagi $P K S$. Ditambah pula, tipikal Andre yang dinilai elit DPD PKS agak susah untuk diatur. Sehingga sosok muda Andre ini cukup menjadi momok bagi mereka," ungkap salah seorang kader PKS.

Untuk lebih memahami analisis semiotika Roland Barthes tentang kegagalan komunikasi iklan politik Andre Rosiade terhadap PKS dapat dilihat dalam tabel berikut ini.

Tabel Analisis Tanda dan Makna Semiotis Komunikasi Politik Andre dalam Bentuk Media Iklan

\begin{tabular}{|c|c|c|c|c|}
\hline \multirow[t]{2}{*}{ No } & \multirow{2}{*}{$\begin{array}{c}\text { Sign } \\
\text { (Tanda) }\end{array}$} & \multirow[t]{2}{*}{ Signifier (Penanda) } & \multicolumn{2}{|c|}{ Signfied (Petanda) } \\
\hline & & & Denotatif & Konotatif \\
\hline 1 & 'Simbol' & 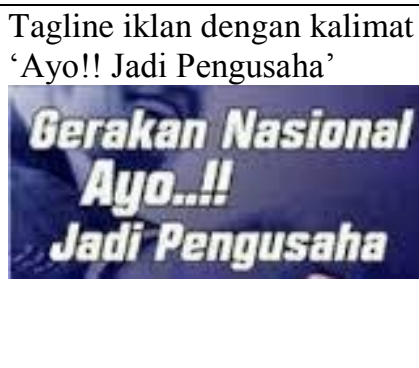 & $\begin{array}{l}\text { Menyatakan ia ingin } \\
\text { berbuat untuk daerah } \\
\text { dengan mengajak dan } \\
\text { mendidik para pemuda } \\
\text { untuk jadi pengusaha. }\end{array}$ & $\begin{array}{l}\text { Iklan ini merupakan } \\
\text { bentuk perkenalan } \\
\text { terselubung Andre } \\
\text { kepada masyarakat } \\
\text { bahwa ia ingin menjadi } \\
\text { pemimpin di Kota } \\
\text { Padang dan tindakan } \\
\text { mencuri start } \\
\text { kampanye }\end{array}$ \\
\hline 2 & 'Simbol' & 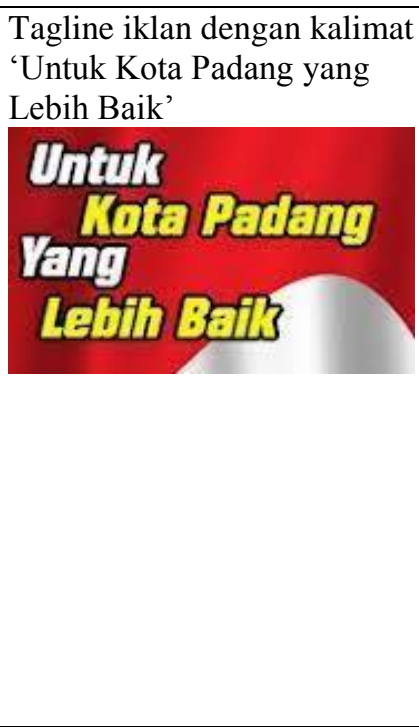 & $\begin{array}{l}\text { Andre mencitrakan diri } \\
\text { sebagai sosok } \\
\text { 'pahlawan' dalam } \\
\text { menyelesaikan masalah } \\
\text { dalam kehidupan } \\
\text { masyarakat Kota } \\
\text { Padang ke depan. Ia } \\
\text { menganggap bahwa } \\
\text { dirinya adalah orang } \\
\text { yang berpengalaman, } \\
\text { mengetahui masalah } \\
\text { daerah dan juga solusi } \\
\text { untuk mengatasinya }\end{array}$ & $\begin{array}{l}\text { Tagline itu hanya } \\
\text { pencitraan semata. } \\
\text { Karena Andre dinilai } \\
\text { belum berpengalaman } \\
\text { dalam mengurus } \\
\text { pemerintahan jika } \\
\text { dibandingkan dengan } \\
\text { pak Emzalmi. } \\
\text { Sehingga PKS lebih } \\
\text { memutuskan untuk } \\
\text { berkoalisi dengan } \\
\text { Emzalmi daripada } \\
\text { Andre, sekalipun } \\
\text { secara survey, } \\
\text { popularitas dan } \\
\text { elektabilitas Andre } \\
\text { jauh lebih tinggi dari } \\
\text { Emzalmi. }\end{array}$ \\
\hline
\end{tabular}




\begin{tabular}{|c|c|c|c|c|}
\hline 2 & 'Simbol' & 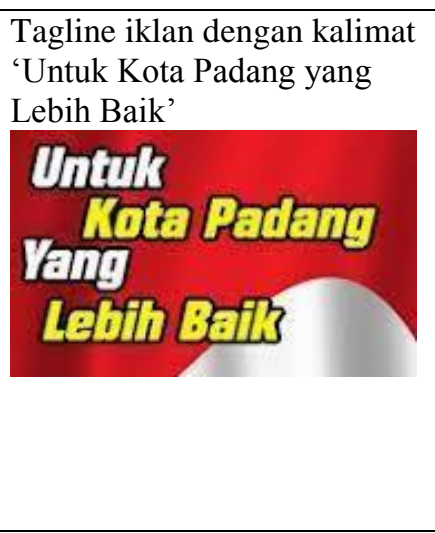 & $\begin{array}{l}\text { Menyatakan bahwa } \\
\text { Andre membawa } \\
\text { sesuatu yang 'baru' } \\
\text { bagi masyarakat Kota } \\
\text { Padang, yang } \\
\text { dianggapnya kian } \\
\text { terpuruk, dengan } \\
\text { demikian ia membawa } \\
\text { program-program } \\
\text { perubahan untuk Kota } \\
\text { Padang yang lebih baik } \\
\text { kedepannya. }\end{array}$ & $\begin{array}{l}\text { Merupakan suatu } \\
\text { bentuk topeng politik } \\
\text { Andre. Baik tagline } \\
\text { ataupun program yang } \\
\text { Andre munculkan } \\
\text { tersebut bukanlah } \\
\text { sesuatu yang istimewa } \\
\text { untuk Kota Padang. } \\
\text { Bahkan hal tersebut } \\
\text { terkesan biasa saja jika } \\
\text { dibandingkan dengan } \\
\text { program dari bakal } \\
\text { calon lainnya. }\end{array}$ \\
\hline 3 & 'Ikon' & $\begin{array}{l}\text { Gambar Andre di dalam } \\
\text { Baliho yang menampakkan } \\
\text { wajah tampan dengan mimik } \\
\text { tersenyum, bahasa tubuh yang } \\
\text { menampakkan kegagahan }\end{array}$ & $\begin{array}{l}\text { Andre dinilai sebagai } \\
\text { sosok seorang 'tokoh } \\
\text { muda' yang } \\
\text { mempunyai sikap } \\
\text { pemberani dengan } \\
\text { mengiklankan dirinya } \\
\text { sebagai calon } \\
\text { pemimpin muda untuk } \\
\text { Kota Padang. }\end{array}$ & $\begin{array}{l}\text { Kedepan sosok 'Andre } \\
\text { muda' merupakan } \\
\text { 'ancaman' dalam } \\
\text { perebutan kekuasaan. } \\
\text { Karena Andre } \\
\text { dianggap dapat } \\
\text { menjadi rival yang } \\
\text { tangguh dikemudian } \\
\text { hari nanti. Oleh karena } \\
\text { itu, sosok Andre yang } \\
\text { disebut sebagai 'tokoh } \\
\text { muda' menjadi } \\
\text { perhitungan politik } \\
\text { tersendiri bagi PKS } \\
\text { dimasa yang akan } \\
\text { datang }\end{array}$ \\
\hline
\end{tabular}

\section{PENUTUP}

\section{Kesimpulan}

Dari hasil penelitian dan pembahasan, dapat disimpulkan bahwa komunikasi politik yang dibangun Andre dengan intens melalui media tidak cukup meyakinkan PKS untuk mengusung dirinya menjadi walikota. Bagi Andre, komunikasi politik yang ia lakukan dianggap selalu memiliki makna yang denotatif, akan tetapi justru dianggap memiliki makna konotatif bagi partai politik tersebut.

\section{Saran}

Berdasarkan temuan data mengenai kegagalan komunikasi politik, maka untuk strategi pemenangan yang baik untuk dilakukan kedepan yaitu:

1. kandidat, akan tetapi juga berpengaruh bagi keindahan dan kebersihan Bagi setiap kandidat yang ingin maju ke pentas politik seperti pemilu ataupun pilkada, hendaknya berbuat secara nyata terlebih dahulu ditengah-tengah masyarakat jauh sebelum pemilu atau pilkada tersebut dilaksanakan. Buatlah program-program pembangunan atau pemberdayaan yang riil dirasakan manfaatnya oleh masyarakat.

2. Bagi setiap kandidat yang sudah pasti menyatakan diri untuk maju ke pentas politik pemilu ataupun pilkada, hendaklah mempersiapkan diri dengan 
berbagai perencanaan dan strategi pemenangan yang matang. Khusus dalam pilkada, Undang-Undang memberikan dua jalur untuk maju sebagai calon, yakni melalui jalur Partai Politik dan jalur independen. Dengan demikian, para kandidat harus mempunyai kemantapan hati apakah akan maju lewat jalur parpol atau independen. Ada baiknya, syarat-syarat untuk melewati dua jalur tersebut harus dipersiapkan semua. Sehingga, kalaupun gagal maju lewat jalur parpol, maka masih bisa melalui jalur independen.

3. Iklan politik memang kadangkala mempunyai pengaruh yang besar terhadap peningkatan popularitas seorang bakal calon atau kandidat ditengah masyarakat, akan tetapi tidak sepenuhnya terhadap elektabilitasnya. Banyak bakal calon yang telah mengeluarkan dana yang besar untuk membiayai iklan-iklan politiknya, namun iklan tersebut tidak mempengaruhi keputusan masyarakat untuk memilihnya. Oleh karena itu, untuk menghemat biaya, ada baiknya setiap kandidat dalam strategi kampanyenya tidak lagi fokus pada iklan-iklan politik yang 'bisu.' Akan tetapi lebih baik memperbanyak metode tatap muka yang efektif.

4. Bagi pemerintah, baik legislatif maupun eksekutif, hendaknya masing-masing membuat sebuah formula untuk mengatasi komunikasi dalam bentuk iklan-iklan politik (terutama media luar ruang seperti baliho, spanduk, banner) yang menjamur saat moment pemilu atau pilkada. Iklan-iklan politik ini tidak saja sering dinilai tidak efektif bagi kesuksesan seorang lingkungan. Mungkin dengan membuat sebuah regulasi yang bijak dalam membatasinya.

\section{DAFTAR PUSTAKA}

Baiquni, Adi. 2009 "Pengaruh Tingkat Pengetahuan Tentang Iklan Politik Televisi Terhadap Sikap Politik Pemilih Pemula Di Kecamatan Klojen Kota Malang. 'Skripsi pada Fakultas Psikologi Universitas Islam Negeri Maulana Malik Ibrahim Malang.

Fenyapwain, Marissa Marlein. Pengaruh Iklan Politik Dalam Pemilukada Minahasa Terhadap Partisipasi Pemilih Pemula Di Desa Tounelet Kecamatan Kakas, Journal "Acta Diurna" Volume I. No. 1 Tahun 2013.

Mulyana, Deddy. 'Menimbang Iklan Politik di Media Massa Menjelang Pemilihan Presiden 2004'. Jurnal Mediator, Vol.5, No 3, 2002

Rozak, Achmad Fuad Abdul. 2009. "Iklan Politik Caleg dalam Persepsi Pemilih Pemula: Study Deskriptif Kualitatif Tentang Iklan Politik Caleg DPRD II Surakarta Melalui Media Luar Ruang Dalam Persepsi Pemilih Pemuladi SMA Negeri III Surakarta." Skripsi pada Ilmu Komunikasi Fakultas Ilmu Sosial Dan Ilmu Politik Universitas Sebelas Maret Surakarta.

Satries, Wahyu Ishardino. "Politik Tak Berjiwa : Fenomena Iklan Politik Dan Artis Berpolitik Di Indonesia”. Jurnal LPPM: PARADIGMA, 2011 - ejournal-unisma.net.

Suryatna, Undang. 2009. "Hubungan Karakteristik Pemilih dan Terpaan Informasi Kampanye Poilitik dengan Perilaku Memilih: Kasus Pemilihan Bupati dan Wakil Bupati Cianjur Tahun 2006." Tesis pada Program Studi Komunikasi Pembangunan Pertanian dan Pedesaan Institut Pertanian Bogor.

Susanto, Eko Harry. (2012). "Iklan Politik dan Kegagalan Partai Politik”. Skripsi pada Fakultas Ilmu 
Komunikasi

Universitas

Tarumanagara Jakarta

Tinarbuko, Sumbo. (2009). "Menakar

Iklan Politik Pemilu 2009”. Jurnal
Desain Komunikasi Visual

Nirmana, Vol. 11, No. 2, Juli 2009. 